\title{
Kajian Drainase Kawasan Polda Jatim
}

\author{
S. Kamilia Aziz ${ }^{1 *}$, Ismail Sa'ud ${ }^{1}$, M. Hafiizh $I^{1}$., M. Khoiri ${ }^{1}$ \\ Departemen Teknik Infrastruktur Sipil, ITS, Surabaya ${ }^{1}$ \\ Koresponden*, Email: kamilia@ce.its.ac.id
}

\begin{tabular}{ll}
\hline \multicolumn{1}{c}{ Info Artikel } & Abstract \\
\hline Diajukan 5 Pebruari 2017 & Flooding annualy occurs in East Java Police office area because the elevation of the area is \\
Diperbaiki 13 Pebruari 2018 & relatively low when it is compared with the elevation of the outlet channel. When the outlet \\
Disetujui 28 Pebruari 2018 & canal is full or flooded, the water in the area cannot be drained in to the channel. In this study, \\
capacity of the existing channel and the method to stop water overflow from outside into the & Police office area are evaluated. The results show that some of the existing channel need to \\
be normalized. To overcome the overflow water, semi-polder system need to be applied, water & barrier with high of $30 \mathrm{~cm}$ need to be constructed at the area perimeter and installed sluice at \\
the every outlet. Moreover, all the surface water from area inside the perimeter is temporary \\
retained in additional pond and will be pumped in to outlet channel via the middle channel \\
when the channel has low water level. The additional pond is required to be able to retain \\
T248.42 $\mathrm{m}^{3}$ of water for Q5 and $7697.48 \mathrm{~m}^{3}$ of water for Q10. Using $0,5 \mathrm{~m}^{3} / \mathrm{sec}$ pump capacity, \\
total discharge time of the pond is 4 hours for $Q 5$ and 4.27 hours for Q10.
\end{tabular}
total discharge time of the pond is 4 hours for Q5 and 4.27 hours for Q10.

\begin{abstract}
Abstrak
Persoalan banjir di kawasan Polda Jatim disebabkan karena elevasi kawasan yang relatif sama dengan elevasi outlet sehingga ketika saluran outlet penuh atau tergenang, maka kawasan ini tidak dapat mengalirkan air ke outlet. Pada kajian ini dievaluasi kemampuan saluran eksisting mengalirkan debit banjir dan upaya menahan air dari luar kawasan tidak masuk ke dalam. Dari hasil perhitungan didapatkan bahwa beberapa saluran perlu dinormalisasi. Untuk mengatasi luberan air dari luar kawasan, diterapkan sistem semi polder, sekeliling kawasan ditinggikan $30 \mathrm{~cm}$ dan dibangun pintu pada tiap-tiap outlet. Air yang tertahan didalam kawasan ditampung di kolam tampungan dan dipompa keluar ke saluran tengah ketika saluran sudah surut. Volume kolam tampungan yang dibutuhkan sebesar 7248.42 $\mathrm{m}^{3}$ untuk Q5 dan $7697.48 \mathrm{~m}^{3}$ untuk Q10. Lama pengosongan kolam tampungan menggunakan pompa eksisting dengan debit $0.5 \mathrm{~m}^{3} / \mathrm{dt}$ adalah 4 jam untuk Q5 dan 4.27 jam untuk Q10.
\end{abstract}

\section{Pendahuluan}

Pesatnya pembangunan menuntut dibangunnya prasarana-prasarana pendukung seperti jalan, saluran drainase, dll. Bangunan baru biasanya dibuat lebih tinggi karena sudah disesuaikan dengan kajian kondisi curah hujan dan debit yang melimpas. Sedangkan bangunan lama, elevasinya tetap sehingga cenderung lebih rendah jika dibandingkan dengan bangunan baru. Perbedaan elevasi ini merupakan sebuah tantangan baru. Bangunan lama, yang elevasinya cenderung lebih rendah dibandingkan bangunan baru, kalah bersaing dalam mengalirkan debit aliran ketika musim hujan.

Tataguna lahan merupakan salah satu faktor yang berpengaruh pada besarnya debit banjir yang terjadi pada suatu daerah aliran sungai. Nilai tataguna lahan ini digambarkan dalam besaran koefisien pengaliran[1]. Menurut Didik dkk, kerentanan suatu daerah terhadap banjir tergantung banyak faktor, antara lain bentuk topografi, kapasitas infiltrasi lahan, tutupan lahan dan tinggi curah hujan[2].

Hal inilah yang melatarbelakangi diadakannya kajian drainase kawasan Polda Jatim. Diduga penyebab banjir yang terjadi di kawasan ini adalah elevasi kawasan yang lebih rendah dibandingkan dengan elevasi outlet saluran, sehingga terjadi backwater dan airnya menggenangi kawasan tersebut. Sebelum dibangun frontage A. Yani, kawasan Polda Jatim memiliki kolam tampungan yang cukup luas, namun sekarang kolam tampungan tersebut mengecil, dan berubah fungsi menjadi frontage dan bangunan masjid Polda Jatim. Sejak pembangunan kedua fasilitas tersebut, kawasan Polda Jatim selalu tergenang setiap terjadi hujan cukup lebat. Pada kejadian hujan pada tanggal 24 november 2017, frontage Barat depan rumah sakit bhayangkara sampai gedung graha pena tergenang sampai $30 \mathrm{~cm}$, sehingga secara otomatis kawasan Polda Jatim juga tergenang. 


\section{Metode}

Langkah pertama dalam penelitian adalah pengukuran topografi pada kawasan Polda Jatim. Pengukuran topografi mengetahui arah aliran air. Pengukuran tofografi dimulai dengan pengukuran patok-patok BM dengan GPS Geodetik. Hasil pengukuran patok BM seperti pada gambar 1. BM ini selanjutnya akan dipakai sebagai acuan untuk pengukuran situasi dan long-cross saluran dan kolam tampungan.

Langkah berikutnya adalah perhitungan curah hujan rencana. Pos Penakar hujan yang berpengaruh di kawasan Polda Jatim adalah Pos Penakar Hujan Kebonagung. Menurut Aziz dan Sa'ud, Curah hujan rencana kawasan Kebonagung untuk periode ulang 2 tahun $=74 \mathrm{~mm}$, periode ulang 5 tahun $=102 \mathrm{~mm}$, dan periode ulang 10 tahun $=120 \mathrm{~mm}[3]$. Namun, karena kawasan Polda Jatim tidak terlalu luas (18 ha), maka dipertimbangkan untuk menghitung ulang curah hujan rencana. Untuk analisa debit persaluran, memakai rumus Rational, sedangkan perhitungan debit rencana untuk perhitungan kebutuhan pompa memakai rumus Nakayasu[4].

Dari hasil perhitungan fullbank saluran eksisting, dan debit rencana akan dievaluasi kemampuan saluran eksisting mengalirkan debit rencana. Saluran yang tidak mampu mengalirkan debit rencana akan di normalisasi supaya dapat mengalirkan debit rencana. Saluran-saluran yang dinormalisasi direncanakan menggunakan U-Ditch, sehingga dimensi rencana disesuaikan dengan ukuran yang tersedia di pabrikan.

Untuk mengatasi adanya aliran back water, maka dicoba dengan sistem semi polder. Pada sistem polder, air dari luar kawasan yang dilindungi polder tidak boleh masuk ke dalam. Namun, tanggul yang terlalu tinggi juga terlalu riskan karena kawasan ini cukup padat lalu lintasnya sehingga pintu-pintu masuk kawasan sebaiknya jangan ditanggul terlalu tinggi sehingga menyulitkan pengendara yang keluar masuk kawasan, sebaiknya cukup selevel dengan tinggi genangan yang biasanya terjadi diluar kawasan (frontage barat A. Yani) sehingga air dari luar tidak bisa masuk kedalam, demikian juga outlet-outlet saluran dipasang pintu sehingga ketika muka air outlet lebih tinggi pintu ditutup, dan air dari luar tidak bisa masuk kedalam kawasan. Sementara air hujan yang jatuh didalam kawasan akan ditampung dalam kolam tampungan (polder) sampai air di outlet turun elevasinya, baru kemudian air dalam polder dikosongkan. Namun, jika genangan lebih tinggi dari tanggul yang sudah direncanakan, maka air tetap akan dapat masuk ke dalam kawasan, sehingga dalam kajian ini tidak menerapkan sistem polder penuh, melainkan sistem semi polder.

\section{Hasil dan Pembahasan}

Kawasan Polda Jatim berdasarkan hasil pengukuran dengan GPS Geodetik berada pada posisi X= 91900015, $\mathrm{Y}=6911146$, lebih lengkapnya seperti gambar 1 . Dari hasil pengukuran tofografi didapatkan bahwa elevasi kawasan relatif datar dengan kemiringan rata-rata 1/10000. Sebagai contoh saluran S1, elevasi tanggul saluran +33.660 , sedangkan elevasi frontage +33.783 jika tebal paving $6 \mathrm{~cm}$ dan tebal beton wiremesh juga $6 \mathrm{~cm}$ maka elevasi tanggul saluran frontage adalah + 33.663 artinya level atas saluran S1 sama dengan level atas saluran frontage A. Yani, sehingga ketika frontage tergenang, maka saluran dalam kawasan Polda Jatim tidak dapat mengalirkan air ke saluran frontage, sehingga mengakibatkan terjadinya genangan. Hal yang sama terjadi pada saluran di outlet 3-6. Skema sistem drainase kawasan Polda Jatim dapat dilihat pada gambar 2. Sedangkan pada saluran S13 pada posisi outlet 8, elevasi tanggul saluran S13 +33.841 , sedangkan elevasi tanggul saluran tengah pada sisi outlet 8 adalah +33.312 , artinya elevasi tanggul saluran tengah pada posisi outlet 8 lebih rendah dibandingan elevasi tanggul saluran S13, sehingga jika level air maksimal adalah +33.312, menyesuaikan posisi tanggul elevasi tengah.

Pada kawasan Polda Jatim sudah dilengkapi dengan kolam tampungan dengan volume $1483,5 \mathrm{~m}^{3}$, seperti terlihat pada gambar 1. Dari hasil perhitungan didapatkan bahwa curah hujan rencana untuk periode ulang 2 tahun $=93,78$ $\mathrm{mm}$, periode ulang 5 tahun $=106.54 \mathrm{~mm}$, dan periode ulang 10 tahun $=113,14 \mathrm{~mm}$. berdasarkan data dari BMKG bahwa hujan lebat pada tanggal 30 Mei 2016 pada kisaran 110 mm, dan pada tanggal 24 Nopember 2017, curah hujan pada pos penakar Keboagung setinggi $112 \mathrm{~mm}$. dua kejadian hujan ini menyebabkan banjir yang cukup parah, frontage A. Yani tergenang sampai $30 \mathrm{~cm}$, sehingga kawasan Polda Jatim secara otomatis juga ikut tergenang, dan kedua curah hujan tersebut mendekati curah hujan periode ulang 10 tahun, curah hujan yang cukup tinggi dan keluar dari fenomena bahwa periode ulang sepuluh tahun terjadi hampir 2 kali dalam dua tahun berturut-turut diduga akibat adanya badai yang terjadi di dekat Indonesia, sehingga menyebabkan cuaca ekstrem. Sehingga, untuk keamanan saluran drainase pada kawasan Polda Jatim dihitung dengan periode ulang 5 tahun dan 10 tahun.

Hasil analisis debit rencana dengan metode Rational dan kapasitas saluran eksisting didapatkan bahwa saluran S1, S3B, S3C, S6, S11, S12, dan S23 masih belum mampu mengalirkan debit rencana baik itu Q5 maupun Q10, sehingga perlu dinormalisasi. Rencana normalisasi saluran seperti terlihat pada tabel 1.

Persoalan kedua yang dihadapi adalah ketika muka air outlet sudah penuh atau sudah tergenang, maka untuk mengatasi persoalan ini disiasati dengan menjadikan kawasan ini 
kawasan semi polder, artinya menahan air untuk sementara didalam kawasan, kemudian memompa keluar ketika air di outlet elevasinya sudah meungkinkan untuk menerima air dengan batasan tinggi tanggul adalah $30 \mathrm{~cm}$ saja, jika genangan lebih dari $30 \mathrm{~cm}$, maka tetap aka nada air yang masuk ke dalam kawasan Polda Jatim. Hal ini dipilih supaya tanggul tidak terlalu tinggi dan menyulitkan pengendara yang keluar masuk kawasan Polda Jatim. Selain itu dari kejadian hujan, tinggi genangan di saluran frontage rata-rata sekitar 30 $\mathrm{cm}$. untuk pembuatan sistem semi polder ini, maka sekeliling kawasan ditinggikan setinggi $30 \mathrm{~cm}$, sedangkan pada masing-masing outlet di bangun pintu air untuk mengatur keluar masuknya air. Sistem operasional pintu dibuat ketika muka air saluran sudah sama dengan muka air outlet, maka pintu air ditutup sehingga air akan mengalir ke kolam tampungan di bagian belakang kawasan. Menurut Aziz dkk, kolam tampungan merupakan salah satu alternatif yang dapat digunakan jika kodisi lapangan tidak memungkinkan dengan solusi normalisasi[5][6]. Menurut Sa'ud dan Wiguna, dari penelitian didapatkan kesesuaian Alternatif terbaik untuk pengendalian Volume Limpasan di tiap-tiap wilayah di Surabaya untuk luas lahan $<600 \mathrm{~m}^{2}$ menggunakan sumur resapan, luas lahan 601 sampai dengan $1000 \mathrm{~m}^{2}$ menggunakan Long Storage dan luas lahan $>1000 \mathrm{~m}^{2}$ menggunakan kolam tampungan[1].

Tabel 1. Rencana Normalisasi Saluran yang Meluber

\begin{tabular}{ccccccc}
\hline $\begin{array}{c}\text { nama } \\
\text { saluran }\end{array}$ & $\begin{array}{c}\text { Qfull } \\
\text { bank } \\
\mathrm{m} 3 / \mathrm{dt}\end{array}$ & \multicolumn{2}{c}{ Desain } \\
$\mathrm{B}(\mathrm{m})$ & $\begin{array}{c}\mathrm{H} \\
(\mathrm{m})\end{array}$ & $\mathrm{m} 3 / \mathrm{dt}$ & $\mathrm{m} 3 / \mathrm{dt}$ & $\mathrm{m} 3 / \mathrm{dt}$ \\
\hline $\mathrm{S} 1$ & 1.118 & 2.8 & 1.5 & 2.661 & 2.428 & 2.578 \\
$\mathrm{~S} 3 \mathrm{~B}$ & 0.052 & 0.4 & 0.6 & 0.072 & 0.056 & 0.060 \\
$\mathrm{~S} 3 \mathrm{C}$ & 0.034 & 0.4 & 0.6 & 0.072 & 0.044 & 0.047 \\
$\mathrm{~S} 6$ & 0.2452 & 1.0 & 1.0 & 0.690 & 0.642 & 0.682 \\
$\mathrm{~S} 11$ & 0.025 & 0.5 & 0.6 & 0.084 & 0.072 & 0.076 \\
$\mathrm{~S} 12$ & 0.032 & 0.3 & 0.4 & 0.066 & 0.053 & 0.056 \\
$\mathrm{~S} 15$ & 0.193 & 0.8 & 1.0 & 0.278 & 0.209 & 0.222 \\
$\mathrm{~S} 23$ & 0.098 & 0.7 & 0.8 & 0.138 & 0.104 & 0.110 \\
\hline
\end{tabular}

Sumber: hasil perhitungan

Untuk menampung air ketika tidak bisa dialirkan keluar kawasan, maka perlu dievaluasi apakah kolam tampungan eksisting sudah mencukupi. Kolam eksiting yang ada di kawasan Polda Jatim sebesar $1483.5 \mathrm{~m}^{3}$. Dengan rumus Nakayasu dihitung kebutuhan kolam tampungan dengan periode ulang 5 tahun seperti terlihat pada tabel 2 sebesar $7248.42 \mathrm{~m}^{3}$. Sedangkan kebutuhan kolam tampungan untuk periode ulang 10 tahun seperti terlihat pada tabel 3 sebesar $7697.48 \mathrm{~m}^{3}$. Kolam tampungan ini direncanakan untuk dapat menampung http://dx.doi.org/10.12962/j2579-891X.v16i1.3558 seluruh volume hujan yang turun dari awal hujan sampai selesai hujan, supaya kawasan ini benar-benar aman. Sehingga diasumsikan bahwa selama hujan, seluruh air dapat tertampung di dalam kolam.

Tabel 2. Kebutuhan Kolam Tampung dengan Q5 tahun

\begin{tabular}{rrrr}
\hline \multicolumn{1}{c}{$\mathrm{t}$} & $\begin{array}{c}\text { Q Inflow } \\
\text { (jam) }\end{array}$ & \multicolumn{1}{c}{$\begin{array}{c}\text { Vol Inflow } \\
(\mathrm{m} 3 / \text { detik })\end{array}$} & $\begin{array}{c}\text { Vol Inflow } \\
\text { komulatif } \\
(\mathrm{m} 3)\end{array}$ \\
\hline 0 & 0.00000 & 0.00000 & 0.00 \\
0.1 & 1.57865 & 284.15626 & 284.16 \\
0.16 & 6.14492 & 834.14478 & 1118.30 \\
0.2 & 5.57929 & 844.14324 & 1962.44 \\
0.3 & 3.61469 & 1654.91658 & 3617.36 \\
0.39 & 2.24353 & 949.03043 & 4566.39 \\
0.4 & 2.18017 & 79.62659 & 4646.02 \\
0.5 & 1.53128 & 668.06138 & 5314.08 \\
0.6 & 1.07552 & 469.22348 & 5783.30 \\
0.7 & 0.75541 & 329.56654 & 6112.87 \\
0.73 & 0.67944 & 77.48166 & 6190.35 \\
0.8 & 0.50945 & 149.80018 & 6340.15 \\
0.9 & 0.39086 & 162.05688 & 6502.21 \\
1 & 0.29988 & 124.33403 & 6626.54 \\
2 & 0.02119 & 577.93070 & 7204.47 \\
3 & 0.00150 & 40.84144 & 7245.31 \\
4 & 0.00011 & 2.88620 & 7248.20 \\
5 & 0.00001 & 0.20396 & 7248.40 \\
6 & 0.00000 & 0.01441 & 7248.42 \\
\hline Sumber: hasil perhitungan & &
\end{tabular}

Untuk pengosongan kolam tampung, air dipompa keluar menuju saluran tengah (S24) Menggunakan pompa eksisting dengan debit sebesar $0.5 \mathrm{~m}^{3} / \mathrm{dt}$. Pengosongan kolam dilakukan ketika saluran di outlet sudah mulai kosong, supaya debit yang keluar tidak menyebabkan banjir di sekitar saluran outlet. Lama pengosongan kolam jika memanfaatkan pompa yang ada yaitu 2 pompa dengan debit total $0.5 \mathrm{~m} / \mathrm{dt}$, maka waktu pengosongan yang dibutuhkan selama 4 jam untuk Q5 (tabel 4, gambar 4) dan 4.27 jam untuk Q10 (tabel 5, gambar 5). Namun jika dikehendaki waktu pengosongan lebih cepat, maka debit pompa dapat ditambah.

\section{Simpulan}

Berdasarkan hasil dan pembahasan dapat disimpulkan bahwa penyebab terjadi banjir pada kawasan drainase Polda Jatim adalah beberapa saluran tidak mampu mengalirkan debit banjir sehingga beberapa saluran dinormalisasi supaya mampu mengalirkan debit banjir. 
Untuk mengatasi genangan dikawasan Polda Jatim direncanakan dengan sistem semi polder, sekeliling kawasan ini dilindungi dengan tanggul setinggi $30 \mathrm{~cm}$ dan pembuatan pintu-pintu air pada tiap-tiap outlet, sehingga kawasan ini terlindung dari air dari luar kawasan, kecuali jika tinggi genangan di luar kawasan lebih tinggi dari $30 \mathrm{~cm}$, maka air masih dapat masuk ke dalam kawasan.

Tabel 3. Kebutuhan Kolam Tampung dengan Q10 tahun

\begin{tabular}{|c|c|c|c|}
\hline $\begin{array}{c}\mathrm{t} \\
(\mathrm{jam})\end{array}$ & $\begin{array}{l}\text { Q Inflow } \\
\text { (m3/detik) }\end{array}$ & $\begin{array}{l}\text { Vol Inflow } \\
\text { (m3) }\end{array}$ & $\begin{array}{l}\text { Vol Inflow } \\
\text { komulatif } \\
\text { (m3) }\end{array}$ \\
\hline 0 & 0.000 & 0.000 & 0.00 \\
\hline 0.1 & 1.676 & 301.761 & 301.76 \\
\hline 0.16 & 6.526 & 885.822 & 1187.58 \\
\hline 0.2 & 5.925 & 896.440 & 2084.02 \\
\hline 0.3 & 3.839 & 1757.443 & 3841.47 \\
\hline 0.39 & 2.383 & 1007.826 & 4849.29 \\
\hline 0.4 & 2.315 & 84.560 & 4933.85 \\
\hline 0.5 & 1.626 & 709.450 & 5643.30 \\
\hline 0.6 & 1.142 & 498.293 & 6141.59 \\
\hline 0.7 & 0.802 & 349.984 & 6491.58 \\
\hline 0.73 & 0.722 & 82.282 & 6573.86 \\
\hline 0.8 & 0.541 & 159.081 & 6732.94 \\
\hline 0.9 & 0.415 & 172.097 & 6905.04 \\
\hline 1 & 0.318 & 132.037 & 7037.08 \\
\hline 2 & 0.023 & 613.735 & 7650.81 \\
\hline 3 & 0.002 & 43.372 & 7694.18 \\
\hline 4 & 0.000 & 3.065 & 7697.25 \\
\hline 5 & 0.000 & 0.217 & 7697.46 \\
\hline 6 & 0.000 & 0.015 & 7697.48 \\
\hline
\end{tabular}

Sumber: hasil perhitungan
Untuk menampung air selama tidak dapat mengalirkan air keluar kawasan, maka kebutuhan volume kolam tampungan sebesar $7248.42 \mathrm{~m}^{3}$ untuk perencanaan periode ulang 5 tahun dan kebutuhan volume kolam tampungan sebesar $7697.48 \mathrm{~m}^{3}$ untuk perencanaan periode ulang 10 tahun

Lama pengosongan kolam jika menggunakan pompa eksisting dengan debit $0.5 \mathrm{~m} 3 / \mathrm{dt}$ sekitar 4 jam untuk periode ulang 5 tahun dan dan 4.27 jam untuk periode ulang 10 tahun.

\section{Daftar Pustaka}

[1] I. Sa'ud and I. P. A. Wiguna, "Penentuan Alternatif Penanggulangan Genangan Akibat Peubahan Tataguna Lahan di Wilayah Surabaya,” in Prosiding Seminar Nasional Manajemen Teknologi XVII, 2013, p. B-6-1-B-6-8.

[2] D. Harijanto, Kuntjoro, Saptarita, Pudiastuti, and E. Maulani, "Penentuan Indeks Kerentanan Banjir Berindikator Pola Hujan dan Pola Musim," in Seminar Nasional Aplikasi Teknologi Prasarana Wilayah (ATPW), 2014, pp. A1-A8.

[3] S. K. Aziz and I. Sa’ud, "Pola Distribusi Hujan Kota Surabaya," J. Apl. Tek. Sipil, vol. 14, no. 1, pp. 9-16, Feb. 2016.

[4] B. Triatmodjo, Hidrologi Terapan, Cetakan Ketiga. Yogyakarta: Beta Offset, 2013.

[5] S. K. Aziz, I. Sa'ud, A. Kurniawan, and W. Ramadhan, "Detention Basin sebagai Alternatif Penanggulangan Banjir di daerah Ketintang Surabaya," in Seminar Nasional Apilkasi Prasarana Wilayah, 2014, p. A..125-A.130.

[6] S. K. Aziz, "Pola Pengendalian Banjir pada Bagian Hilir Saluran Primer Wonorejo Surabaya," J. Apl. Tek. Sipil, vol. 9, no. 2, p. 33, Aug. 2011. 
Tabel 4. Waktu Pengosongan Kolam dengan debit pompa 0.5 m³/dt

\begin{tabular}{|c|c|c|c|c|c|c|c|}
\hline $\begin{array}{c}\mathrm{t} \\
(\mathrm{jam}) \\
\end{array}$ & $\begin{array}{l}\text { Q Inflow } \\
\text { (m3/detik) }\end{array}$ & $\begin{array}{c}\text { Vol } \\
\text { Inflow } \\
\text { (m3) }\end{array}$ & $\begin{array}{c}\text { Vol Inflow } \\
\text { komulatif } \\
\text { (m3) }\end{array}$ & $\begin{array}{l}\text { Q Outflow } \\
\text { (m3/detik) }\end{array}$ & $\begin{array}{c}\text { Vol } \\
\text { Outflow } \\
\text { (m3) }\end{array}$ & $\begin{array}{c}\text { Vol Outflow } \\
\text { komulatif } \\
\text { (m3) }\end{array}$ & $\begin{array}{l}\text { Selisih } \\
\text { inflow- } \\
\text { outflow } \\
\text { (m3) }\end{array}$ \\
\hline 0 & 0.00000 & 0.00 & 0.00 & & & 0 & \\
\hline 0.1 & 1.57865 & 284.16 & 284.16 & 0.5 & 180 & 180 & 104.16 \\
\hline 0.16 & 6.14492 & 834.14 & 1118.30 & 0.5 & 108 & 288 & 830.30 \\
\hline 0.2 & 5.57929 & 844.14 & 1962.44 & 0.5 & 72 & 360 & 1602.44 \\
\hline 0.3 & 3.61469 & 1654.92 & 3617.36 & 0.5 & 180 & 540 & 3077.36 \\
\hline 0.39 & 2.24353 & 949.03 & 4566.39 & 0.5 & 162 & 702 & 3864.39 \\
\hline 0.4 & 2.18017 & 79.63 & 4646.02 & 0.5 & 18 & 720 & 3926.02 \\
\hline 0.5 & 1.53128 & 668.06 & 5314.08 & 0.5 & 180 & 900 & 4414.08 \\
\hline 0.6 & 1.07552 & 469.22 & 5783.30 & 0.5 & 180 & 1080 & 4703.30 \\
\hline 0.7 & 0.75541 & 329.57 & 6112.87 & 0.5 & 180 & 1260 & 4852.87 \\
\hline 0.73 & 0.67944 & 77.48 & 6190.35 & 0.5 & 54 & 1314 & 4876.35 \\
\hline 0.8 & 0.50945 & 149.80 & 6340.15 & 0.5 & 126 & 1440 & 4900.15 \\
\hline 0.9 & 0.39086 & 162.06 & 6502.21 & 0.5 & 180 & 1620 & 4882.21 \\
\hline 1 & 0.29988 & 124.33 & 6626.54 & 0.5 & 180 & 1800 & 4826.54 \\
\hline 2 & 0.02119 & 577.93 & 7204.47 & 0.5 & 1800 & 3600 & 3604.47 \\
\hline 3 & 0.00150 & 40.84 & 7245.31 & 0.5 & 1800 & 5400 & 1845.31 \\
\hline 4.02678 & 0.00001 & 0.01 & 7248.21 & 0.5 & 48 & 7248 & 0.00 \\
\hline
\end{tabular}

Sumber: hasil perhitungan

Tabel 5. Waktu Pengosongan Kolam dengan debit pompa 0.5 m³/dt

\begin{tabular}{|c|c|c|c|c|c|c|c|}
\hline $\begin{array}{c}\mathrm{t} \\
(\mathrm{jam}) \\
\end{array}$ & $\begin{array}{l}\text { Q Inflow } \\
\text { (m3/detik) }\end{array}$ & $\begin{array}{c}\text { Vol Inflow } \\
\text { (m3) }\end{array}$ & $\begin{array}{c}\text { Vol Inflow } \\
\text { komulatif } \\
\text { (m3) }\end{array}$ & $\begin{array}{l}\text { Q Outflow } \\
\text { (m3/detik) }\end{array}$ & $\begin{array}{c}\text { Vol } \\
\text { Outflow } \\
\text { (m3) }\end{array}$ & $\begin{array}{c}\text { Vol Outflow } \\
\text { komulatif } \\
\text { (m3) }\end{array}$ & $\begin{array}{l}\text { Selisih inflow- } \\
\text { outflow } \\
\text { (m3) }\end{array}$ \\
\hline 0 & 0.00000 & 0.00000 & 0.00 & & & 0 & \\
\hline 0.1 & 1.67645 & 301.76055 & 301.76 & 0.5 & 180 & 180 & 121.76 \\
\hline 0.16 & 6.52561 & 885.82244 & 1187.58 & 0.5 & 108 & 288 & 899.58 \\
\hline 0.2 & 5.92495 & 896.44033 & 2084.02 & 0.5 & 72 & 360 & 1724.02 \\
\hline 0.3 & 3.83863 & 1757.44341 & 3841.47 & 0.5 & 180 & 540 & 3301.47 \\
\hline 0.39 & 2.38252 & 1007.82558 & 4849.29 & 0.5 & 162 & 702 & 4147.29 \\
\hline 0.4 & 2.31524 & 84.55968 & 4933.85 & 0.5 & 18 & 720 & 4213.85 \\
\hline 0.5 & 1.62615 & 709.44969 & 5643.30 & 0.5 & 180 & 900 & 4743.30 \\
\hline 0.6 & 1.14215 & 498.29322 & 6141.59 & 0.5 & 180 & 1080 & 5061.59 \\
\hline 0.7 & 0.80221 & 349.98413 & 6491.58 & 0.5 & 180 & 1260 & 5231.58 \\
\hline 0.73 & 0.72153 & 82.28187 & 6573.86 & 0.5 & 54 & 1314 & 5259.86 \\
\hline 0.8 & 0.54101 & 159.08073 & 6732.94 & 0.5 & 126 & 1440 & 5292.94 \\
\hline 0.9 & 0.41508 & 172.09677 & 6905.04 & 0.5 & 180 & 1620 & 5285.04 \\
\hline 1 & 0.31846 & 132.03688 & 7037.08 & 0.5 & 180 & 1800 & 5237.08 \\
\hline 2 & 0.02250 & 613.73516 & 7650.81 & 0.5 & 1800 & 3600 & 4050.81 \\
\hline 3 & 0.00159 & 43.37168 & 7694.18 & 0.5 & 1800 & 5400 & 2294.18 \\
\hline 4 & 0.00011 & 3.06501 & 7697.25 & 0.5 & 1800 & 7200 & 497.25 \\
\hline 4.27628 & 0.00001 & 0.05984 & 7697.31 & 0.5 & 497 & 7697 & 0.00 \\
\hline
\end{tabular}

Sumber: hasil perhitungan 


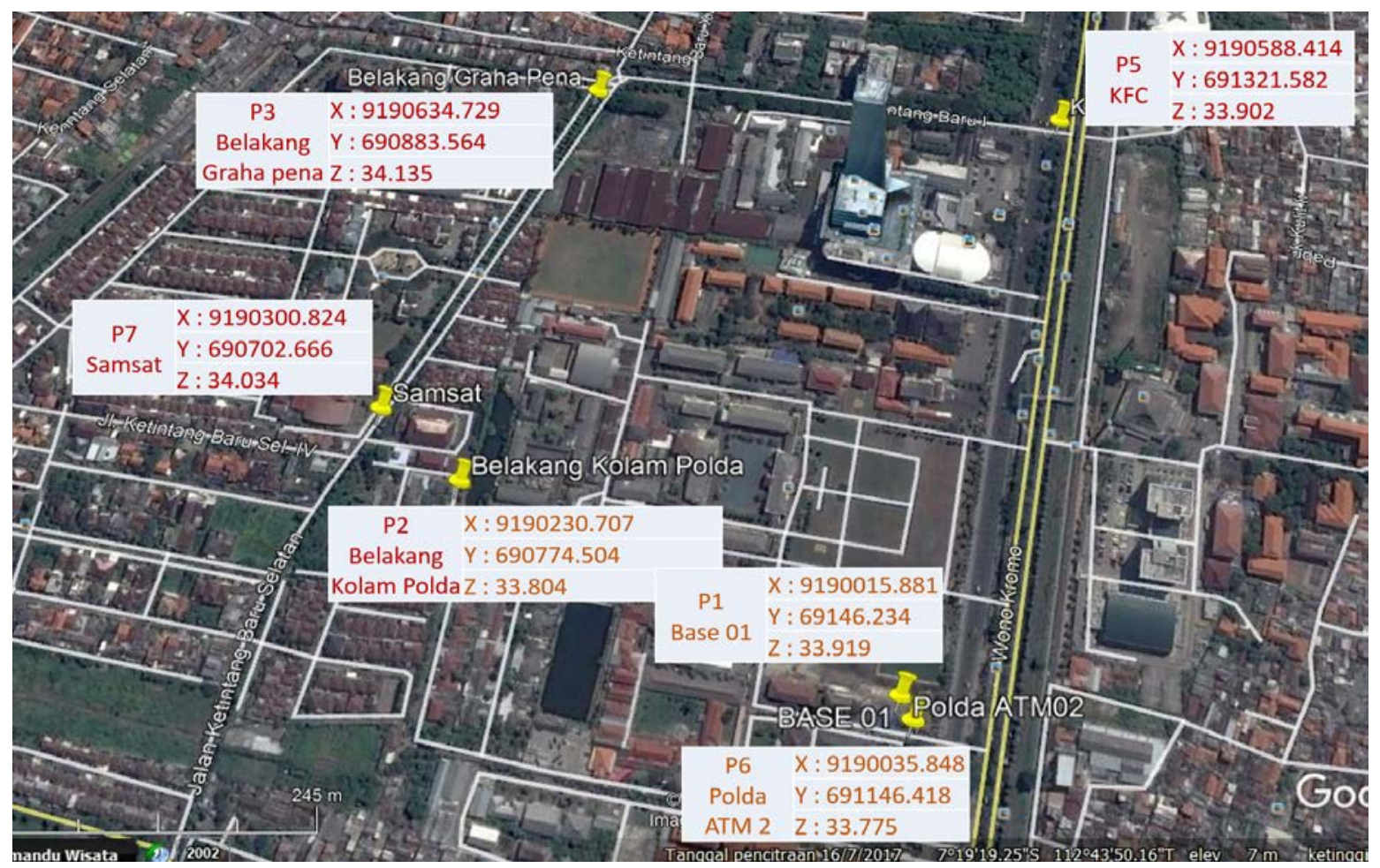

Gambar 1. Hasil Pengukuran BM kawasan Polda Jatim

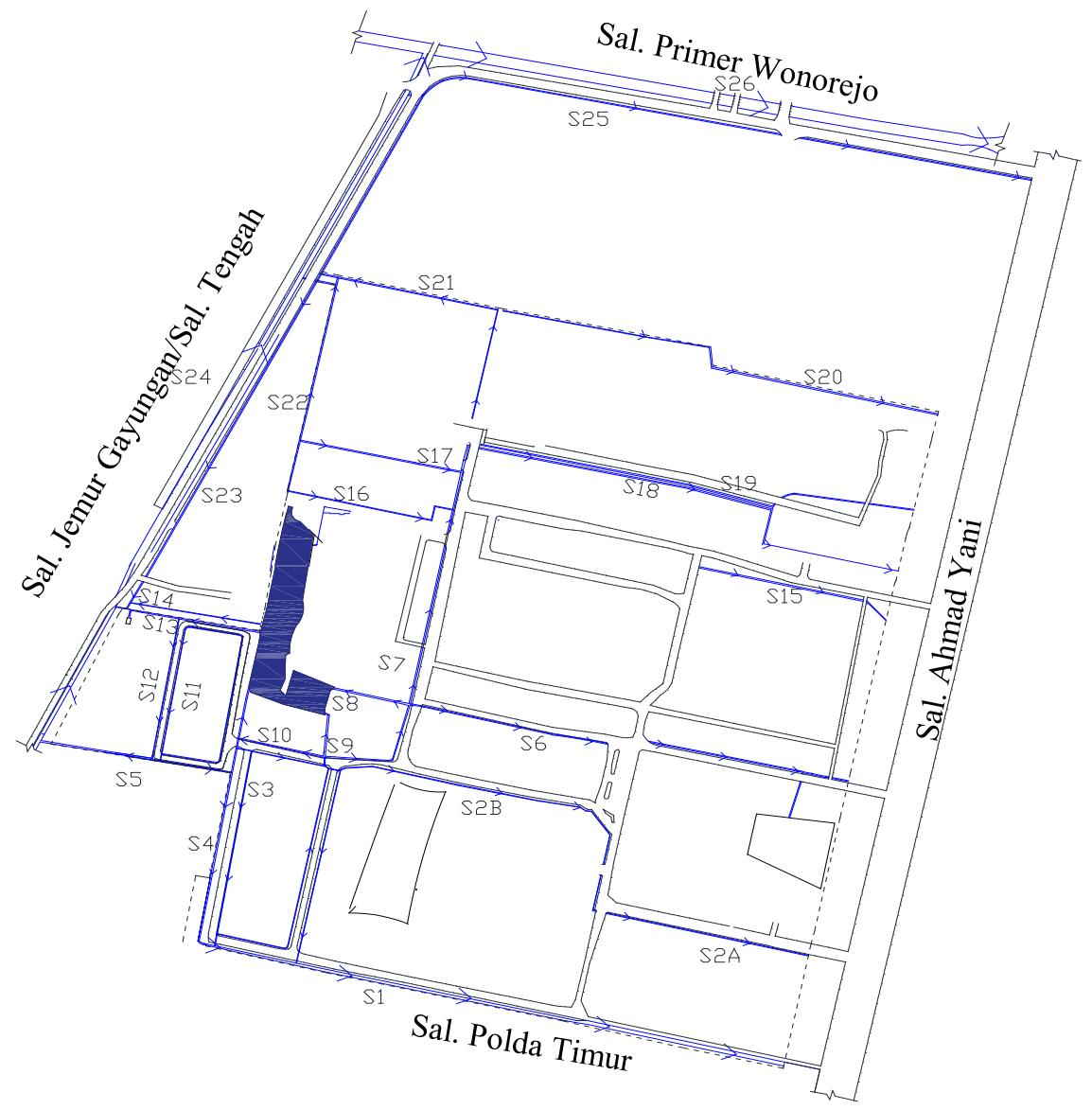

Gambar 2. Skema sistem drainase kawasan Polda Jatim 


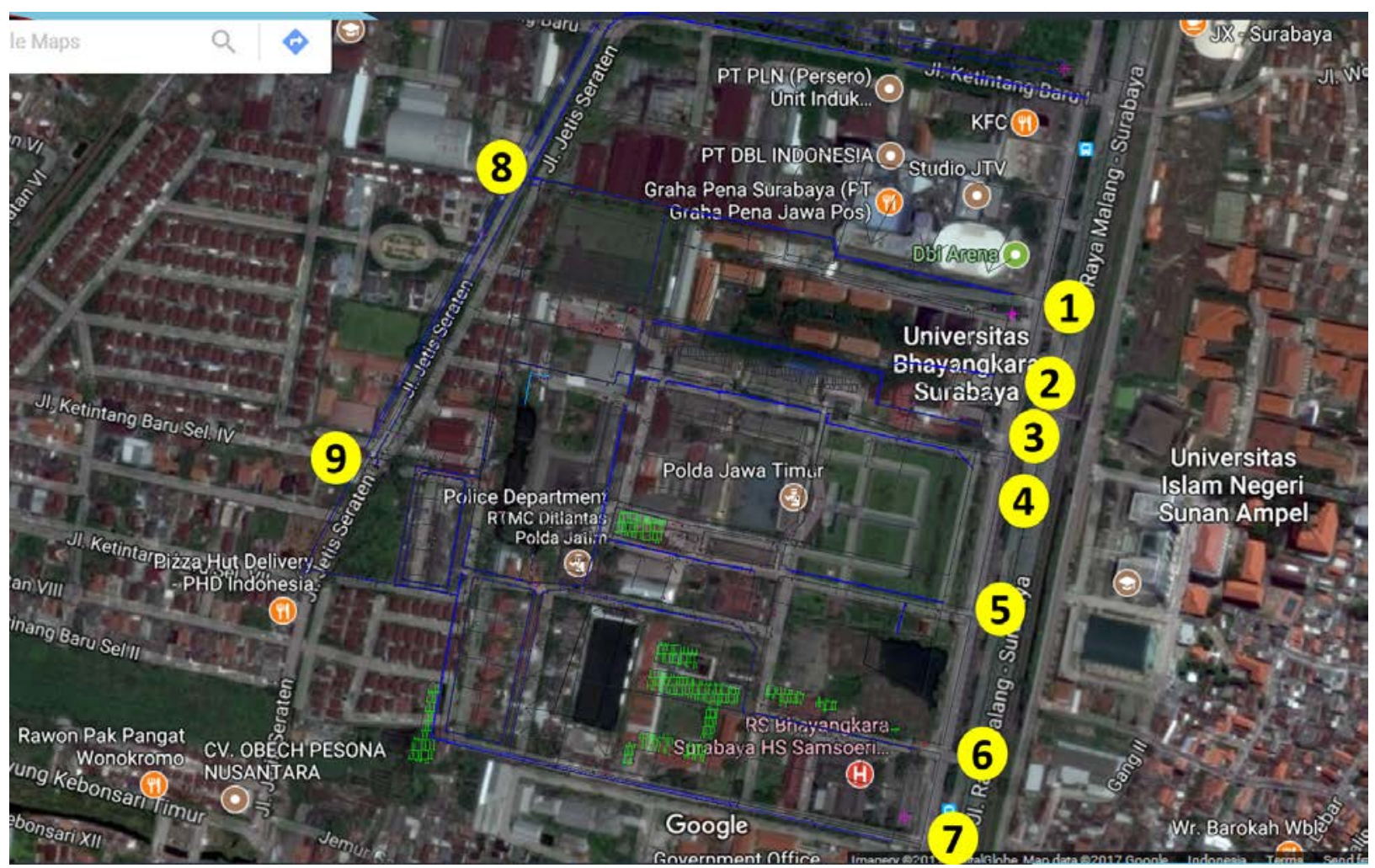

Gambar 3. Posisi Outlet Sistem Drainase Polda Jatim

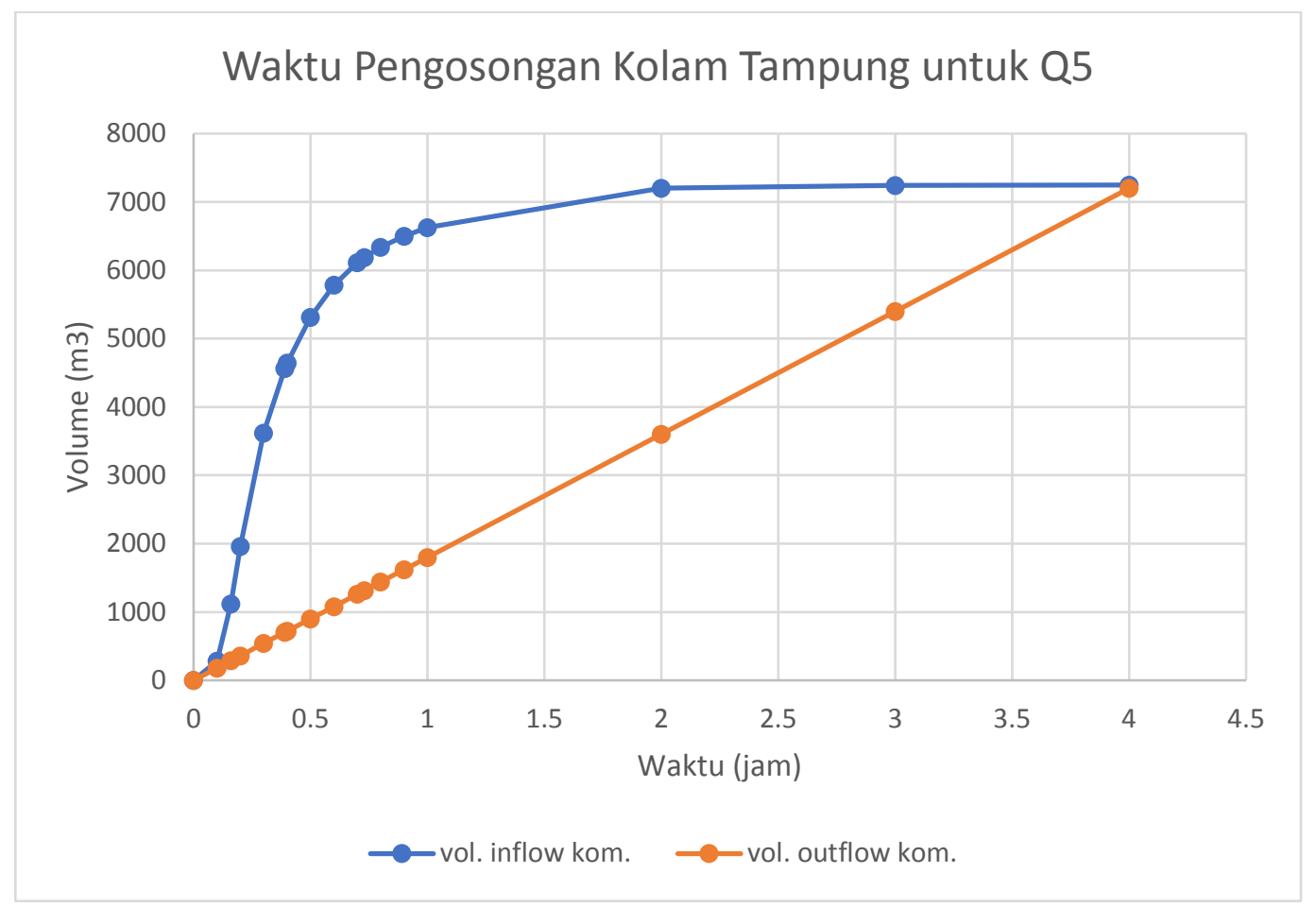

Gambar 4. Waktu Pengosongan Kolam Tampungan untuk $\mathrm{Q}_{5}$ dengan debit pompa 0.5 m³/dt 


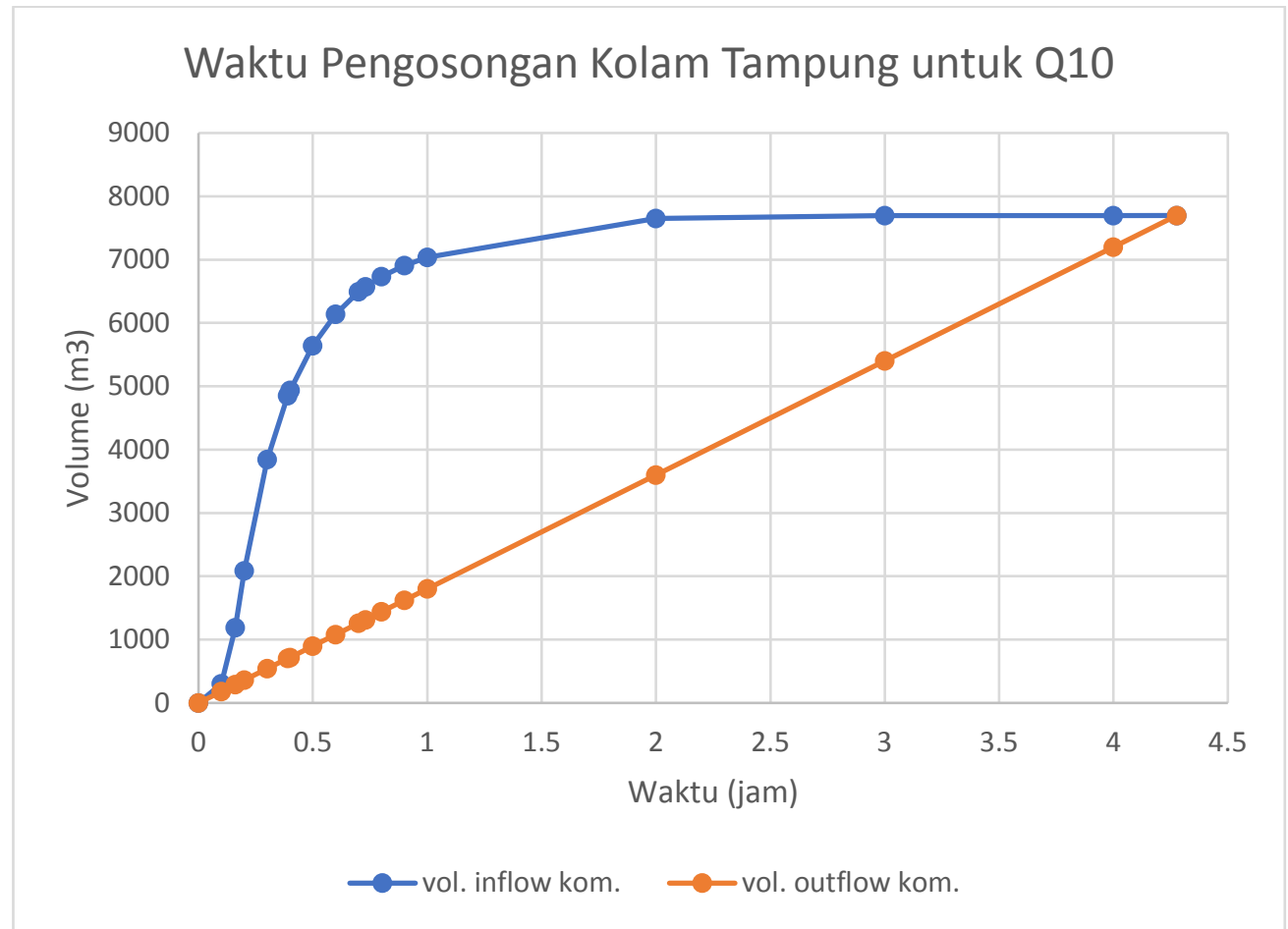

Gambar 5. Waktu Pengosongan Kolam Tampungan untuk $\mathrm{Q}_{10}$ dengan debit pompa 0.5 m³/dt 